\title{
Increasing Fund Sources of Indonesia Sharia Commercial Banks through Public Stock Insurance
}

\author{
Ida Syafrida ${ }^{1}$, Indianik Aminah ${ }^{2}$, Herbirowo Nugroho $^{3}$, Taufik Awaludin ${ }^{4}$ \\ \{ida.syafrida@akuntansi.pnj.ac.id ${ }^{1}$, indianik.aminah@akuntansi.pnj.ac.id ${ }^{2}$, \\ herbirowo.nugroho@akuntansi.pnj.ac.id ${ }^{3}$, dosen01844@unpam.ac.id ${ }^{4}$ \} \\ Politeknik Negeri Jakarta, Indonesia ${ }^{1,2,3}$ \\ Universitas Pamulang, Indonesia ${ }^{4}$
}

\begin{abstract}
The research problem is Islamic Commercial Banks (ICB) market share in Indonesia still low (5.74\% of national banks) in Dec 2017. This is due to the lack of capital and industrial scale. For this reason, the ICB needs to increase external funding sources through the issuance of public shares. From the 13 ICB in Indonesia at the middle of 2018, 3 ICB issuing public shares (Bank Dubai Panin Syariah, Bank Rakyat Indonesia Syariah, Bank Tabungan Pensiunan Nasional Syariah). This study aims to formulate the Benefit, Opportunities, Cost, Risk (BOCR) aspects faced by Islamic Commercial Banks in increasing funding sources through the issuance of public stock securities. This study uses qualitative and quantative methods using primary data sourced from indepth interviews to explore the knowledge and experience of the emiten from Treassury Division and Corporate Planing expert practitioners. Secondary data was from emission prospectus, several research journals and related books. Based on Analysis Network Process (ANP) of BOCR aspects, the dominant aspect being the consideration of ICB in issuing public shares is the Benefit and Opportunity. The dominant sub-aspects of each aspect are increasing capital (Benefit aspects), broad investor base (Opportunity aspects), underwriting costs (Cost aspects), demands for information disclosure (Risk aspects).
\end{abstract}

Keywords: public shares, Islamic Commercial Banks, dominant aspects, BOCR, ANP

\section{Introduction}

The Islamic financial services industry in Indonesia experienced significant growth. Indonesia is predicted to become one of the countries that become a global player in the Islamic financial industry in the world. Indonesia ranks 10th after Qatar and Jordan in the development of the world's halal industry which includes Islamic Finance [1]. In terms of investment, Indonesia in the top three after Malaysia and the United Arab Emirates [2]. Indonesia's 6th position in the world Islamic finance industry after the United Arab Emirates and Kuwait, up one rank compared to 2015[3]. Indonesia is also listed as the country's largest sukuk issuer in the world 2016.

Since December 2017 there are 13 Islamic Commercial Bank, 21 Sharia Unit Network, and 167 Sharia Rural Bank in Indonesia. Data on Islamic Banking during the period 20132017 , total assets increased by an average of $17.02 \%$ per year, financing disbursed per year on average rose $11.03 \%$, and third party funds experienced an average increase of $16.47 \%$ per year. Likewise, the role of Islamic banking intermediation is empirically better, with the average Financing to Deposit Ratio (FDR) for the 2013-2017 period of $91.86 \%$ compared to conventional banking Loan to Deposit Ratio (LDR) (90.39\%). The role of intermediation is 
very important because Islamic banking acts as a commercial banking and investment banking that can drive the real economy sector and productivity.

Furthermore, the Financial Services Authority (FSA) in the 2015-2019 Islamic Banking Road Map explained that there were several strategic issues faced and had an impact on the development of Islamic banking including inadequate capital and small scale industries and individual banks. For this reason, policies need to be directed towards strengthening capital and ICB business scale, because the market share of sharia banking to national banks in Dec 2017 only reach $5.74 \%$.

So, that the contribution of Islamic banks to the national economy is still not optimal. Until the end of Dec 2017, from the 13 ICBs there were only 1 ICB that had been included in the BUKU (Commercial Bank Business Activities) scale 3 (core capital Rp 5 Trillion up to Rp. 30 Trillion). The others of 12 ICBs are in the BUKU scale 2 and 1 (core capital below Rp 5 Trillion). Thus additional funding is needed for the development of Islamic banks.

The limitations of Islamic banks' internal funding sources can be overcome by using external sources of funds by issuing securities, both debt (bonds/sukuk) and investments (stocks). Participating funding sources are more flexible than debt, because they do not have maturity and there are no routine financial obligations to investors. If by the end of 2017 the Indonesia Stock Exchange (IDX) recorded 42 conventional banks that were listed as issuers, only 1 Islamic banks that had made public offerings and listed their shares on the IDX, Bank Dubai Panin Syariah (BDPS). In 2018, Bank Tabungan Pensiunan Nasional Syariah (BTPNS) and Bank Rakyat Indonesia Syariah (BRIS) have also done Initial Public Offering (IPO). It is expected that other ICB can follow the act of the 3 ICB in issuing public shares.

According to the corporate IDX, the issuance of public shares bring benefit such as new funding sources; provide competitive advantages for ICB business development; merge or acquire other companies by financing through share issuance; and improve the going concern ability, image and value of the company. Poulsena and Stegemollerb [4] show that companies will move to public ownership through an IPO when they have greater growth opportunities. Sulong et al [5] shows that there is no significant difference between the initial performance of sharia and non-sharia IPOs, even after controlling for the characteristics of the IPO.

Based on the description, the problems of Islamic banks to be examined are related to capital and industrial scale and individual banks that are still minimal. This causes Islamic banks to be less able to develop optimally and compete with conventional banks. It is expected that with the addition of capital, Islamic banks can carry out their intermediary roles more optimally and can contribute more to the national economy. To increase the funding source, it is necessary to know the advantages, opportunities, costs, risks and the factors that are considered by the ICB in issuing stock securities based on the knowledge or experience of the emiten experts related to the problem.

\section{Method}

The research population is a Islamic Commercial Bank in Indonesia which at the end of 2017 numbered 13 ICB. The sample of the study consisted of 5 expert practitioners. The practitioners from Treassury Division and Corporate Planning of BDPS, BTPNS, BRIS.

In this study, the main data used is primary data from indepth interviews to explore the knowledge and experience from experts of ICB. The selection of respondents in this study was carried out by purposive sampling and convenience sampling. Sampling is included in the non-probability sample technique [6]. The selected respondents are experts who have knowledge and experience and can answer research questions so that they get theoretical 
insights [7]. Resource persons from the sample of study. Additional data in the form of secondary data obtained from the literature of journals, working papers, books, and publication reports that are closely related to research problems.

The initial stage is carried out in-depth interviews with resource persons with open questions related to the characteristics of funding sources from public shares with BOCR (Benefit, Opportunity, Cost, Risk) approach. To find out the aspects of BOCR use descriptive analysis. Data collection used by conducting indepth interviews with structured questions to the respondents recorded and made decomposition accompanied by the support of literature review related to research problems. After that, the researcher made a questionnaire in the form of a pairwise comparison where the respondents were asked to determine which aspects and sub-aspects were the bigger ones which influenced the output data in the form of a ratio scale.

To determine the dominant factors that influence the increase in low-cost ICB funding as well as formulate the most appropriate strategy, the Analytic Network Process (ANP) method is used. ANP is a mathematical theory in decision making that is able to analyze influences through assumptions to solve various problems [8]. The software for quantitative analysis is Super Decision.

\section{Result and Discussion}

Benefits, Opportunities, Costs and Risks (BOCR) need to be considered by the ICB before deciding to issue shares as a source of funding. This is related to the consequences that will be faced by the ICB after the issuance of shares. The following figure shows the dominant aspect of BOCR based on analysis network process:

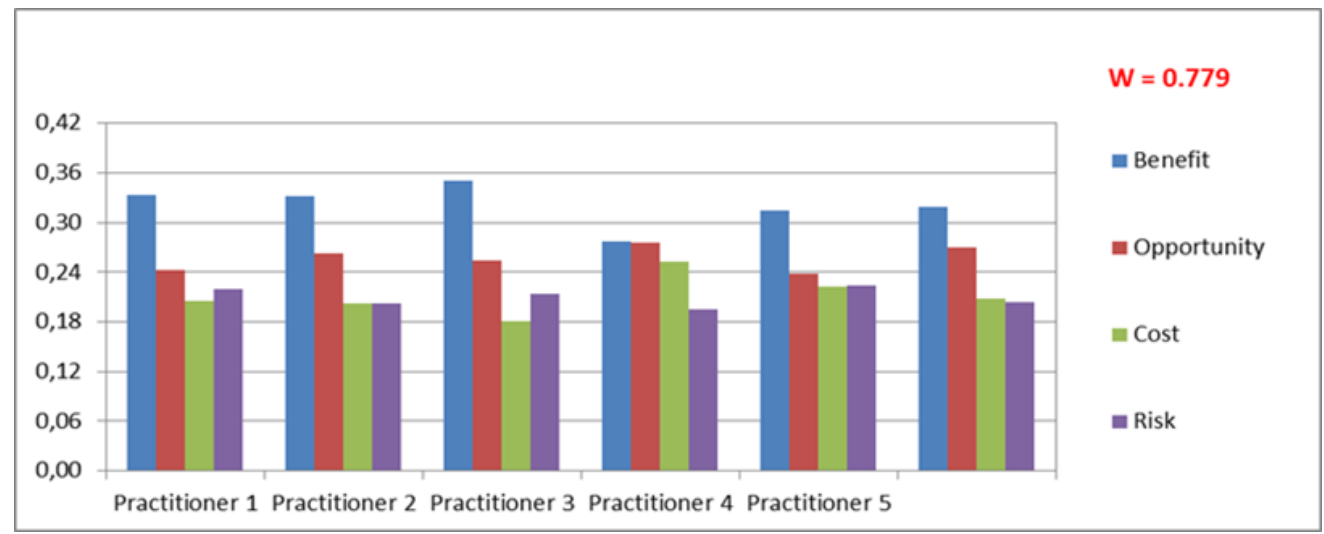

Figure 1: Priority of BOCR Aspects

Based on Figure 1 as a whole, all respondents think that the dominant aspect for ICB in deciding to issue public shares is the benefit aspect followed by the opportunity aspect with a fairly high suitability value $(\mathrm{W}=0.779)$. Then just consider the aspect of cost (cost) and finally the risk aspect (risk). Thus it can be concluded that benefits and opportunities are the dominant aspects for ICB in deciding to issue public shares as a funding source. If the ICB will decide to issue public shares, then the ICB will first consider the aspects of benefit and opportunity that the ICB will obtain from the activity. 
In more detail the ANP results regarding the dominant sub-aspects which are considered by ICB in issuing public shares are as follows:

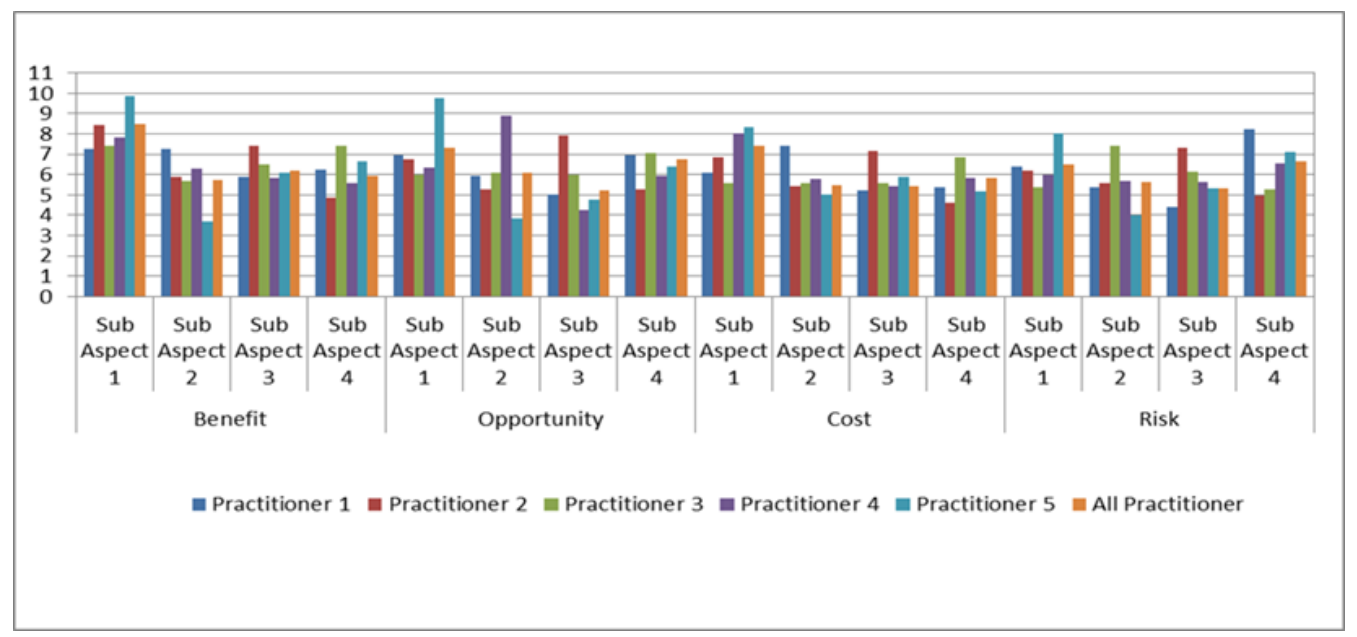

Figure 2: Description of Priorities on BOCR Aspects

In Figure 2, it can be seen as a whole the respondents argue that the dominant sub-aspect of the benefit aspects is increasing capital followed by expanding the ICB business. Thus the main benefit of issuing public shares to ICB is to increase capital. Another benefit of issuing shares for ICB is to expand the ICB business, in this case related to network expansion and the use of information technology which is currently very much needed for the development of Islamic banks.

Seen from the aspects of opportunity, the most important sub-aspect are the broad investor base, then the investment climate is also quite good. Investors who can buy public shares issued by ICB can come from investors who consider sharia factors in investing and general investors, so that the market of Islamic sharia shares is quite extensive. Another opportunity that ICB has in consideration of issuing public shares is the condition of investment in Indonesia, especially investment in the capital market which is quite good and tends to increase. One indicator in this case is the stock price index on the Indonesia Stock Exchange.

The underwriting fee is the most dominant sub-aspect in the cost aspect of underwriters followed by other costs, such as printing, advertising, listing on the stock exchange. The existence of underwriters as underwriters is to assist issuers in the process of going public since the beginning until completion. Underwriters also guarantee the sale of shares offered by the issuer, so the costs for underwriters are also the main thing. ICB shares offered through a public offering will then be listed at the Stock Exchange, for other costs including listing fees also become a consideration of ICB in the issuance of public shares.

In the aspects of risk, the dominant sub-aspect that is considered is the demand for information disclosure and the next sub-aspect is the percentage of ownership decreases. The existence of regulations on information disclosure makes the ICB must be prepared with all standards-appropriate reporting to the Indonesia Financial Fervices Authority (FSA) and the community and has a means of publication for the general public. The risk of reduced 
percentage of ownership is also a major consideration in determining how much new shares will be issued by ICB.

Based on the emission prospectus and the results of interviews obtained information on several aspects of stock issuance based on Benefit, Opportunity, Cost, and Risk, the classification of these aspects are:

\subsection{Benefit aspects}

In the benefit aspects, there are 4 sub-aspects that are considered: a) increasing capital; b) funding sources; c) expanding ICB business networks; c) enhancing the company's reputation.

Until Dec 2017, from 13 only 1 ICB achieve optimal economies of scale (in BUKU scale 3). Based on a study by Bank of Indonesia, corporate banking must increase core capital to more than Rp 5 Trillion or included in the BUKU scale 3. Although the issuance of shares in ICB had not yet increased the BUKU scale, there was an increase in issued and fully paid capital ICB in the range of $11 \%$ up to $100 \%$. In addition to increasing capital, the ICB needs to increase its market share which until Dec 2017 is still less than 6\%. For this reason, the ICB must increase the amount of its assets by increasing the amount of financing as assets with the largest composition. Based on the issuance prospectus data, around $80 \%$ up to $100 \%$ of the proceeds from the issuance of shares after deducting the issuance costs are used to increase the ICB financing. In an effort to increase this financing, the ICB must also add the source of third party funds. This is due to the low number of ICB office networks $(1,825$ offices) compared to Conventional Commercial Banks (32,285 offices) based on banking statistics in Dec 2017. Some of the proceeds from share issuance (up to 20\%), are used by ICB to add office networks and development information technology system. By becoming a public company, ICB is better known by the public and can improve its reputation.

This is in line with the study Woojin\&Weisbac [9], Lee \& Lee [10], Garcia, Durendez, Marino [11] which concluded that the company made a stock offering to increase investment capital, sources of financing, legitimacy and reputation, as well as risk diversification.

\subsection{Opportunity aspects}

The Sub-aspects of opportunity are: a) a broad investor base; b) a fairly good investment climate; c) strong regulatory support; d) a choice of competent underwriters

The opportunity owned by the ICB to issue public shares is a large Islamic financial market, because Indonesia is a big country with a Muslim population of around $80 \%$. This indicates the magnitude of the potential availability of Islamic stock investors. This is evidenced by the sale of ICB shares with an emission value in the range of Rp 500 Billion up to $\mathrm{Rp} 1,338$ Trillion overall oversubcribes. Besides the availability of potential buyers, Indonesia's macroeconomic conditions, especially the investment climate in the Indonesia Stock Exchange, are still in good condition as indicated by the Jakarta Composite Index (JCI), which continued to rise to 6,355.65 at the end of Dec 2017. This also encouraged the ICB to decide to issue shares. Then the support of sharia financial regulators, especially FSA, carried out securities issuance in the Capital Market as reflected in regulations that did not complicate. Reporting provisions for Islamic stock issuers in Indonesia are stipulated by FSA through FSA Regulation No. 17/PFSA.04/2015. Opportunities that are no less important are the capabilities and qualifications of the Underwriters. As of Dec 2017 there were a choice of 22 underwriters in Indonesia, their services gave an important role in the success of the issuance of ICB securities.

These opportunity conditions are in line with The results of Bildik \& Yilmaz [12], Poulsena \& Stegemmolerb [4], Pham, Kalev, Steen [13]. They shows that companies move to 
public ownership through IPOs when they have greater growth opportunities, such as: number of potential investors, an investment bank's reputation, market conditions and market timing.

\subsection{Cost aspects}

Cost aspects consist of 4 sub-aspects: a) costs for underwriting; b) service costs for supporting institutions and professions; c) emission registration fees; d) other costs, such as printing, advertising, listing on the stock exchange.

Based on observations of specific costs incurred by the ICB related to share issuance from the data of the ICB stock issuance prospectus, the total securities issuance costs paid are in the range of $1.696 \%$ up to $3.251 \%$ of the total public offering funds. The largest proportion of costs is the service cost of the emission-supporting institutions and professions, while the proportion of the smallest costs is the cost of registering securities to the FSA.

Costs that are generally borne by companies related to share emissions are discussed in the study Benninga, Helmantel, Sarig [14], Asker, Farre-Mensa, Ljungqvist [15]. The authors have emphasized other costs and benefits of being public, such as costs associated with disclosure requirements or benefits due to a reduction in financing costs, greater scope for risk sharing, and the opportunity to attract better qualified human capital.

\subsection{Risk aspects}

The sub-aspects that are influenced to risk aspects: a) decreasing of ownership percentage; b) ownership change resistance; c) high reporting requirements; d) information disclosure

Issuance of shares has risks, both for company owners and company management. For owners, the issuance of new shares causes a decrease in the percentage of ownership (dilution). Based on observations of ICB stock prospectus data, dilution for the majority shareholders of ICB after the public offering of shares was in the range of $7 \%$ up to $50 \%$. The more ICB offers new shares, the greater the chance of resistance to changes in ownership in the company. The risk faced by management from the company's decision to go public is that there are demands for more complex reporting and information disclosure. Based on Bapepam-LK [16], ICB is required to provide annual financial reports and semi-annual financial reports accompanied by an accountant's report in the framework of the audit to FSA a maximum of 3 months from the reporting date. The report was also announced to the public through at least one Indonesian language daily newspaper with national circulation and published on the website of the issuer or public company that can be accessed at any time [17]. Issuers are also required to report important events that can affect stock prices to FSA and the public.

Several studies discuss the risk of issuing shares for companies. There are costs associated to the decision of going public such as, losing of shareholder control, high reporting requirements, lack of resources and resistance to change [18] [19]. Disclosure requirements that may constrain innovation [20].

\section{Conclusion}

Before issuing shares, ICB needs to consider the aspects of Benefit, Opportunity, Cost, and Risk that influence stock issuance decisions, to understand the positive and negative consequences of the action.

The sub-aspects of Benefit: increasing capital; funding sources; expanding ICB business networks; enhancing the company's reputation. The sub-aspects of Opportunity: broad investor base; a choice of competent underwriters; strong regulatory support; a fairly good 
investment climate. The sub-aspects of Cost: percentage of ownership decreases; ownership change resistance; strict reporting requirements; information disclosure demands. The subaspects of Risk: percentage of ownership decreases; ownership change resistance; high reporting requirements; disclosure of information.

Based on ANP's analysis of aspects of BOCR, the dominant aspect becomes the consideration of ICB in issuing public shares is the Benefit then the Opportunity. The dominant sub-aspects of each aspect are increasing capital (Benefit aspect), broad investor base (Opportunity aspect), underwriting costs (Cost aspect), demands for information disclosure (Risk aspect).

\section{References}

[1] Reuters T, Standard D. 2014. State of the global Islamic economy 2014-2015 report. May, available at: http://halalfocus. net/wp-content/uploads/2015/01/SGIE-Report-2014. pdf."

[2] [UNCTAD] United Nation Conference on Trade and Development. 2015. World Investment Report 2015. 2015. Jenewa(SW): UNCTAD."

[3] World Bank Group, Global Islamic Financial 2016, (2016)."

[4] Poulsena A, Stegemmolerb M. Moving from Private to Public Ownership: Selling Out to Public Firm VS Initial Public Offerings, University of Georgia-Texas Tech University (2005)."

[5] Sulong Z, Embi N.A.C., Arifin M.R. Performance of Initial Public Offerings: Does Sharia Complience Make A Difference? J Accounting, Finance, and ICBiness (IJAB), 2 (6), 190-205 (2017).”

[6] Sekaran U. Research method for ICBiness: a skill building approach. Journal of Education for ICBiness. 68(5): 316-317 (2003).”

[7] Saunders M, Lewis P, Thornhill A. Research Methods For ICBiness Students. Ed ke-5. England(UK): Pearson Education Limited (2009)."

[8] Saaty TL. Theory and Applications of the Analytic Network Process: Decision Making with Benefits, Opportunities, Costs and Risks. Pittsburgh(US): RWS Publications (2005).”

[9] Woojin K, Weisbac M.S. Motivation for Public Equity Offers: An International Perspective, J Financial Economics, February (2008)."

[10] Lee YJ., Lee JD. Strategy of start-ups for IPO timing across high technology industries, Applied Economics Letters, 15(11), 869-877 (2008)."

[11] García-Pérez-de-Lema D, Duréndez A, Mariño T. A strategic decision for growth, financing and survival of Small and Medium Family ICBinesses: Going Public in an Alternative Stock Market (MAB), Economics and Finance Review, 1(8), 31-42 (2011)."

[12] Bildik R, Yilmaz MK.. The market performance of initial public offerings in the Istanbul Stock Exchange (2006)."

[13] Pham PK, Kalev PS, Steen AB. Underpricing, stock allocation, ownership structure and postlisting liquidity of newly listed firms, J Banking \& Finance, 27(5), 919-947 (2003).”

[14] Benninga S, Helmantel M, Sarig O. The timing of initial public offerings, J Financial Economics, 75(1), 115-132 (2005)."

[15] Asker J, Farre-Mensa J, Ljungqvist A. Corporate investment and stock market listing: A puzzle?, The Review of Financial Studies, 28(2), 342-390 (2014).”

[16] [Bapepam-LK] Badan Pengawa Pasar Modal dan Lembaga Keuangan. Keputusan Bapepam dan Lembaga Keuangan No. KEP-346/BL/2011 Tentang Penyampaian Laporan Keuangan Berkala Emiten atau Perusahaan Publik, Jakarta (2011).”

[17] [Bapepam-LK] Badan Pengawa Pasar Modal dan Lembaga Keuangan. Keputusan Bapepam dan Lembaga Keuangan No. KEP-431/BL/2012 Tentang Penyampaian Laporan Tahunan Emiten atau Perusahaan Publik, Jakarta (2012).”

[18] Becchetti L, Trovato G. The determinants of growth for small and medium sized firms. The role of the availability of external finance, Small ICBiness Economics, 19(4), 291-306 (2002)." 
[19] Berggren B, Olofsson C, Silver L. Control aversion and the search for external financing in Swedish SMEs, Small ICBiness Economics, 15(3), 233-242 (2000).”

[20] Wies S, Moorman C. Going public: how stock market listing changes firm innovation behavior, J Marketing Research, 52(5), 694-709 (2015).” 